
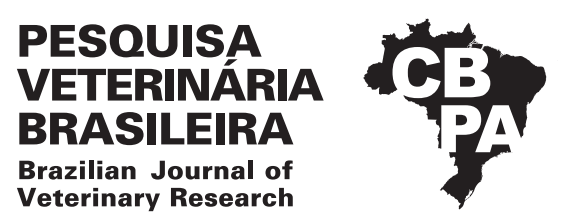

Pesq. Vet. Bras. 38(11):2129-2132, novembro 2018 DOI: $10.1590 / 1678-5150-P V B-5328$

Original Article

ISSN 0100-736X (Print)

ISSN 1678-5150 (Online)

\title{
Histopathological and immunophenotypical assessment of canine primary splenic lymphoma according to the World Health Organization ${ }^{1}$
}

\author{
Cristiano P. Fracácioº , Felipe A.R. Sueiro ${ }^{3}$, Letícia A. Anai ${ }^{4}$, Maiara B. Pucci², \\ Igor L.S. Senhorello ${ }^{4}$, Julielton S. Barata ${ }^{4}$ and Paulo C. Jark ${ }^{2,4 *}$
}

\begin{abstract}
Fracácio C.P., Sueiro F.A.R., Anai L.A., Pucci M.B., Senhorello I.L.S., Barata J.S. \& Jark P.C. 2018. Histopathological and immunophenotypical assessment of canine primary splenic lymphoma according to the World Health Organization. Pesquisa Veterinária Brasileira 38(11):2129-2132. Departamento de Clínica Veterinária e Cirurgia, Faculdade de Ciências Agrárias e Veterinárias, Universidade Estadual Paulista, Via de acesso Prof. Dr. Paulo Donato Castellane s/n, Jaboticabal, SP 14884-900, Brazil. E-mail: paulocjark@hotmail.com

Although there are several studies addressing multicentric lymphoma in dogs, data regarding splenic lymphoma remains scarce. The diagnosis of splenic lymphoma using the World Health Organization (WHO) classification system can aid prognostic characterization of splenic lymphoma. The aim of this study was to evaluate the most common histological types of splenic lymphoma in dogs from Brazil according to the WHO classification. We assessed 33 cases of splenic lymphoma diagnosed by histopathologic and immunohistochemical (IHC) analysis submitted to VETPAT- Pathology Laboratory, Campinas-SP, Brazil. IHC was performed using antibodies against CD3 for T-cell and CD79 $\alpha$ for B-cell identification. Mean age of patients with splenic lymphoma was 9.8 years. The most affected breeds were mixed breed dogs (33\%) followed by Pit bulls and Yorkshires (9.0\%). The most prevalent histological type was marginal zone B-cell lymphoma $(60.7 \%)$ followed by diffuse large B-cell lymphoma (12.1\%) and lymphoblastic T-cell lymphoma (12.1\%). Histological and immunohistochemical characterization of splenic lymphoma is important due to the high prevalence of indolent lymphomas such as marginal zone, which may be less aggressive and thus have different prognostic and distinct forms of treatment when compared to high-grade lymphomas.
\end{abstract}

INDEX TERMS: Histopathology, immunophenotypical, canine, splenic lymphoma, spleen, hematopoietic neoplasm, indolent lymphoma, pathology.

\footnotetext{
RESUMO.- [Avaliação histopatológica e imunofenotípica segundo a classificação da Organização Mundial da Saúde do linfoma esplênico primário em cães.] Embora existam diversos estudos a respeito do linfoma multicêntrico em cães, os dados sobre linfoma esplênico primário são escassos. O diagnóstico do linfoma esplênico utilizando a classificação da Organização Mundial da Saúde (OMS)

${ }^{1}$ Received on October 10, 2017.

Accepted for publication on March 26, 2018.

${ }^{2}$ Departamento de Clínica Veterinária e Cirurgia, Av. Hilário da Silva Passos 950, Parque Universitário, Descalvado, SP 13690-000, Brazil.

${ }^{3}$ Laboratório VETPAT, Cel. Manuel de Morais 146, Jardim Brasil, Campinas, SP 13073-022, Brazil.

${ }^{4}$ Departamento de Clínica Veterinária e Cirurgia, Faculdade de Ciências Agrárias e Veterinárias (FCAV), Universidade Estadual Paulista (Unesp), Via de acesso Prof. Dr. Paulo Donato Castellane s/n, Jaboticabal, SP 14884-900. * Corresponding author: paulocjark@hotmail.com
}

pode melhorar a caracterização da doença. 0 objetivo do estudo foi avaliar os principais tipos de linfoma esplênico primário em cães no Brasil de acordo com a classificação da OMS. Foram avaliados 33 casos de linfoma esplênico diagnosticados por histopatologia e imuno-histoquímica submetidos ao Laboratório de Patologia Veterinária (VETPAT, Campinas/SP). A imuno-histoquímica foi realizada utilizando os anticorpos CD3 para linfomas T, CD79 $\alpha$ para linfomas B. A média de idade dos pacientes com linfoma esplênico foi de 9,8 anos. Os animais sem raça definida (SRD) foram os mais acometidos (33\%) seguidos de PitBulls e Yorkshire $(9,0 \%)$. 0 tipo histológico mais comum foi o linfoma de zona marginal representando $60,7 \%$ dos casos seguido do linfoma difuso de grandes células B $(12,1 \%)$ e linfoma linfoblástico T $(12,1 \%)$. A caracterização histopatológica e imuno-histoquímica do linfoma esplênico é importante devido à alta prevalência de linfomas indolentes como o linfoma de zona marginal, 
que devido ao seu comportamento indolente apresenta prognóstico e tratamento distintos quando comparado aos linfomas de alto grau.

TERMOS DE INDEXAÇÃO: Histopatologia, imunofenotípica, linfoma esplênico, caninos, baço, neoplasia hematopoiética, linfoma indolente, patologia.

\section{INTRODUCTION}

Lymphoma is a malignant neoplasm characterized by lymphoid cell proliferation. The most common presentation of lymphoma is multicentric, which usually involves peripheral lymph nodes and possibly liver, spleen, bone marrow and extranodal sites (Vail et al. 2013).

There are several studies addressing multicentric lymphoma in dogs, yet studies regarding primary splenic lymphoma remain scarce. The most widely used histological classification system for canine lymphoma is the World Health Organization (WHO) classification (Vezzali et al. 2009, Valli et al. 2011, 2013). Recent uses of this system with primary splenic lymphoma have demonstrated that the most common histological type is marginal zone B-cell lymphoma, which shows indolent progression and better prognosis compared to the most common multicentric type, the diffuse large B-cell lymphoma (O'Brien et al. 2013, Van Stee et al. 2015). Marginal zone lymphoma in the spleen has low mitotic rate and slow progression, which represents a challenge for pathologists to reach a diagnosis, due to its similarity with benign marginal zone hyperplasia. This warrants immunohistochemistry or other molecular techniques for correct diagnosis (O'Brien et al. 2013).

The aim of this study was to assess 33 cases of primary lymphoma of the spleen diagnosed through histopathology and immunohistochemistry according to the WHO classification in dogs, seeing that information regarding the epidemiology of this disease in Brazil is scarce.

\section{MATERIALS AND METHODS}

The research was performed through assessment of the database at VETPAT in Campinas, São Paulo State, Brazil. Samples from the eight regions of the country diagnosed as splenic lymphoma were classified according to the WHO histological and immunohistochemical classification from January 2012 to December 2016.

This study included only splenic lymphoma, and samples diagnosed as other forms of neoplasm such as multicentric, cutaneous, mediastinal, alimentary or extranodal lymphoma were excluded from further analyses. Data regarding patient identification, breed, gender and age were charted for analysis.

Immunohistochemistry (IHC) analysis for immunophenotyping of splenic lymphomas followed pre-stablished protocols, as follows. Immunohistochemical reactions were performed on paraffin-embedded samples sectioned at $4 \mu \mathrm{m}$ and positively charged for immunohistochemical reactions. A biotin-free detection reagent (REVEAL) was used for immunohistochemical analysis. Tissue sections were deparaffinized, rehydrated and incubated for 20 minutes in a $5 \%$ solution of hydrogen peroxide in absolute methanol (Synth) for endogenous peroxidase activity blocking. Heat-induced antigen retrieval was performed using a sodium citrate buffer of $\mathrm{pH} 6.0$ in a pressure cooker. Sections were then washed three times in phosphate-buffered saline (PBS) at $0.01 \mathrm{M}(\mathrm{pH} 7.2)$ for 5 minutes and nonspecific sites were blocked with a blocking buffer for nonspecific reactions (Reveal Spring kit reagent - Cod SPD-125). Slides were incubated overnight with anti-CD3, anti-CD79 $\alpha$ and MUM-1 antibodies, as shown in Table 1.

If positive for CD79 $\alpha$ and negative for CD3, lymphomas were deemed B-cell in origin and T-cell if positive for CD3 and negative for CD79 $\alpha$. Samples that were negative for MUM-1 were regarded as lymphomas and samples that were positive for MUM-1 were regarded as plasma cell tumor.

\section{RESULTS}

Thirty-three cases of primary splenic lymphoma were found in the study. Mean age of patients was 9.8 (5-16) years. Main breeds found were mongrels (11/33), Pit Bulls (3/33), Yorshire Terriers (3/33), Golden Retrievers (2/33), Labradors (2/33), Poodles (2/33), Shih Tzus (2/33), Lhasa Apso (1/33), Rottweiller (1/33), Bernese Mountain Dog (1/33), Pug (1/33), Fox Terrier (1/33), Cane Corso (1/33) and unspecified (1/33). With regard to gender, 18 were males, 14 females and one unspecified.

Immunophenotyping showed that $87.9 \%$ of splenic lymphomas were positive for CD79 $\alpha$ (B-cell) and $12.1 \%$ for CD3 (T-cell). All cases were negative for MUM-1. According the WHO classification system, the most frequent histological type was marginal zone B-cell lymphoma, which accounted for 20 of the 33 cases (60.7\%) (Fig.1), followed by diffuse large B-cell lymphoma $(4 / 33,12.1 \%)$ and lymphoblastic T-cell lymphoma $(4 / 33,12.1 \%)$ (Table2). One case $(3 \%)$ of follicular lymphoma was found among the cases, which summed up to $63.7 \%$ of indolent splenic lymphomas in this study according to the WHO classification.

\section{DISCUSSION}

Lymphoma is a generic term to describe various diseases of unusual origin, which is lymphoid tissue. However, there are variations as to treatment and prognosis according to anatomic location, histological type and immunophenotype

Table 1. Clone, dilution and provenance of antibodies used for immunophenotyping of splenic lymphoma

\begin{tabular}{ccccc}
\hline Antibody & Clone & Dilution & Cod & Manufacturer \\
\hline CD3 & Polyclonal & $1: 300$ & A0452 & DAKO \\
CD79 $\alpha$ & HM47/A9 & $1: 300$ & M7051 & DAKO \\
MUM-1 & MUM1p & $1: 100$ & M7259 & DAKO
\end{tabular}

Table 2. Histopathological classification of primary lymphoma of the spleen in dogs, according to the WHO classification system

\begin{tabular}{lcc}
\hline \multicolumn{1}{c}{ Histological type } & $\begin{array}{c}\text { Number of cases } \\
(\mathrm{N}=33)\end{array}$ & Percentage \\
\hline Marginal zone B-cell lymphoma & 20 & $60.7 \%$ \\
Diffuse large B-cell lymphoma & 4 & $12.1 \%$ \\
Lymphoblastic T-cell lymphoma & 4 & $12.1 \%$ \\
Lymphoplasmacytic lymphoma & 3 & $9.1 \%$ \\
Follicular B-cell lymphoma & 1 & $3 \%$ \\
Lymphocytic B-cell lymphoma & 1 & $3 \%$
\end{tabular}




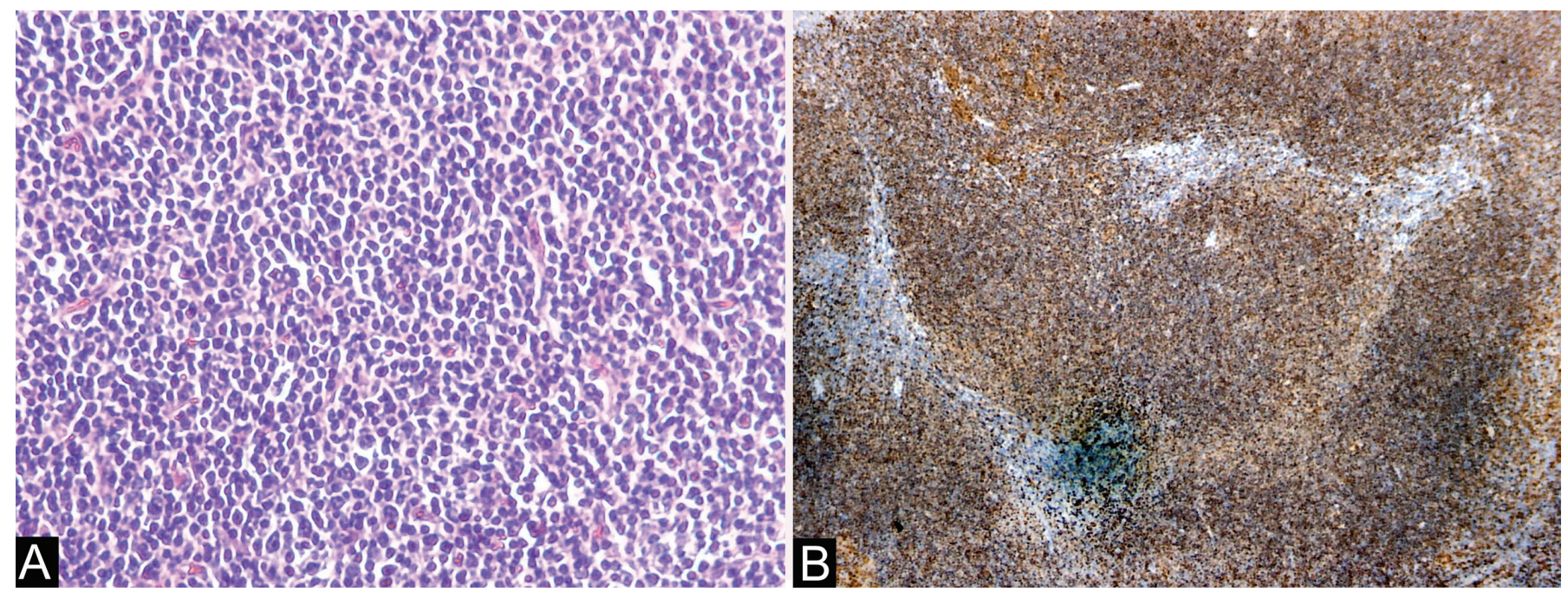

Fig.1. Marginal zone B-cell lymphoma in a dog. (A) Lymphoid neoplasm formed by dense lymphocyte clusters with dense chromatin, reniform nuclei and wide clear cytoplasm. Cells form a dense band that compresses follicular structures. HE, obj.20x. (B) Immunohistochemical analysis of marginal zone B-cell lymphoma in the spleen. Notice the bulk of neoplastic cells positive for CD79 $\alpha$. IHC, obj.4x.

(Rebhun et al. 2011, Marconato et al. 2011, Valli et al. 2013, Goodman et al. 2016). Information regarding treatment and prognosis of lymphoma in dogs is based on studies of various forms of presentation and distinct histological types, which results in heterogeneous groups and therefore difficulties when establishing individualized criteria (Chun 2009, Rebhun et al. 2011, Vail et al. 2013, Goodman et al. 2016).

The study of histopathological characterization of splenic lymphoma in Brazil is somewhat important since current literature is scarce. One study showed low incidence of lymphoma (2.2\%) in 179 cases of splenic diseases (Bandinelli et al. 2011).

Performing a morphological analysis along with immunohistochemistry is crucial to a more accurate classification of the disease and for differentiation of indolent and reaction hyperplasia that can affect the spleen. Although there are several classification systems for canine lymphoma, the WHO classification remains the most commonly used, because it correlates cytomorphological, immunophenotypical and clinical criteria, aside from its agreement among pathologists worldwide (Vezzali et al. 2010, Valli et al 2013). Anti-CD3 and anti-CD79 $\alpha$ antibodies are used for immunophenotyping and described widely due to their high sensitivity and specificity (Valli et al. 2013). The main differential diagnosis for splenic lymphoma during histopathology is plasma cell tumor. One option to aid this distinction is the use of MUM-1, seeing that $93.5 \%$ of extramedullary plasmacytomas are positive for MUM-1, which most lymphomas are negative for (Ramos-Vara et al. 2007). In this study, all cases of splenic lymphomas were negative for MUM-1.

Indolent splenic lymphomas were more prevalent (63.7\%) in this study, of which $60.7 \%$ of the cases were diagnosed as marginal zone B-cell lymphoma. These data corroborate the few studies from other countries, where the incidence of indolent lymphomas in the spleen was higher compared to high grade lymphomas (Van Stee et al. 2015). A study of 28 cases of primary splenic lymphoma showed $71.4 \%$ of indolent tumors and marginal zone B-cell lymphoma was also the most prevalent ( $39.3 \%$ of cases), followed by mantle cell lymphoma (32.1\%) (Van Stee et al. 2015). Interestingly, although mantle cell lymphoma was the second most common in that study, no case of this type was seen in the present study.

The marginal zone B-cell lymphoma is characterized by small to medium size lymphocytes positive for $\operatorname{CD} 79 \alpha$, with low mitotic rate and slow progression, which are originated at the marginal zone of the lymphoid follicle. Since there are only a few reports in the current literature, the incidence of this tumor is unknown (Valli et al. 2006, Stefanello et al. 2011, Flood-Knapik et al. 2013). Valli et al. (2006) reported 66 cases of indolent lymphomas, of which 46 were marginal zone. However, 33 cases were extranodal and only 13 were splenic.

Despite the lack of information regarding the distribution of lymphoma lesions in this study, most of the cases reported by Valli et al. (2006) were characterized as solitary masses found occasionally during ultrasound exams. Other authors also report higher incidence of solitary masses over diffuse presentation or multiple nodes (O'Brien et al. 2013, Stefanello et al. 2011).

No predisposition was found in this study with regard to breed or gender for canine splenic lymphoma, which corroborates previous studies (O'Brien et al. 2013). Most patients were middle-aged to elder, which agrees with most studies of oncology where mean age is usually found to be $>7$ years (Stefanello et al. 2011, Flood-Knapik et al. 2013, O'Brien et al. 2013).

The distinction between indolent and high-grade lymphomas, such as lymphoblastic T-cell lymphoma (12.1\% of the cases) is important, since the prognosis is quite different and they require individualized treatment (Van Stee et al. 2015). One study showed that 1-year survival time for marginal zone lymphoma represents $63.6 \%$ of the cases, whereas high-grade T-cell lymphomas are associated with shorter survival (Van Stee et al. 2015). Another study of 29 cases undergoing splenectomy reported mean survival time of 383 days, and patients that were asymptomatic at the time of surgery showed survival time of 1153 days, which corroborates other studies 
reporting better prognosis with marginal zone lymphomas $\left(O^{\prime}\right.$ Brien et al. 2013). Aside from the exact characterization of histological type, other features are important for choosing treatment, such as differing between localized forms or tumors that involve other organs and the associated clinical signs. These features can influence the prognosis of splenic lymphoma (Stefanello et al. 2011, 0’Brien et al. 2013).

While this was a retrospective study that assessed the incidence of splenic lymphoid neoplasms rather than prognosis, nevertheless the results on prevalence of indolent forms are important to enhance the need for an exact characterization of histological type to aid choice of treatment and prognosis of these cases.

\section{CONCLUSIONS}

Indolent lymphoma represented by marginal zone B-cell lymphoma is the most frequent histological type of splenic lymphomas according to the WHO classification system in dogs.

The exact characterization is fundamental for establishing proper treatment and prognosis of the patients, since current literature show more favorable prognosis in indolent compared to high-grade T- or B-cell lymphomas.

\section{REFERENCES}

Bandinelli M.B., Pavarini S.P., Oliveira E.C., Gomes D.C., Cruz C.E.F. \& Driemeier D. 2011. Estudo retrospectivo de lesões em baços de cães esplenectomizados: 179 casos. Pesq. Vet. Bras. 31(8):697-701. <http://dx.doi.org/10.1590/ S0100-736X2011000800011>

Chun R. 2009. Lymphoma: which chemotherapy protocol and why? Top Companion Anim. Med. 24(3):157-162. <http://dx.doi.org/10.1053/j. tcam.2009.03.003><PMid:19732735>

Flood-Knapik K.E., Durham A.C., Gregor T.P., Sánchez M.D., Durney M.E. \& Sorenmo K.U. 2013. Clinical, histopathological and immunohistochemical characterization of canine indolent lymphoma. Vet. Comp. Oncol. 11(4):272-286. <http://dx.doi.org/10.1111/j.1476-5829.2011.00317. $\mathrm{x}><$ PMid:22296667>

Goodman I.H., Moore A.S. \& Frimberger A.E. 2016. Treatment of canine nonindolent $\mathrm{T}$ cell lymphoma using the VELCAP-TSC protocol: a retrospective evaluation of 70 dogs (2003-2013). Vet. J. 211:39-44. <http://dx.doi. org/10.1016/j.tvjl.2016.03.003><PMid:27017053>

Marconato L., Stefanello D., Valenti P., Bonfanti U., Comazzi S., Roccabianca P., Caniatti M., Romanelli G., Massari F. \& Zini E. 2011. Predictors of long-term survival in dogs with high-grade multicentric lymphoma. J. Am. Vet. Med. Assoc. 238(4):480-485. <http://dx.doi.org/10.2460/javma.238.4.480> <PMid:21320018>

O’Brien D., Moore P.F., Vernau W., Peauroi J.R., Rebhun R.B., Rodriguez Junior C.O. \& Skorupski K.A. 2013. Clinical characteristics and outcome in dogs with splenic marginal zone lymphoma. J. Vet. Intern. Med. 27 (4):949-954. <http://dx.doi.org/10.1111/jvim.12116> <PMid:23734665>

Ramos-Vara J.A., Miller M.A. \& Valli V.E.O. 2007. Immunohistochemical detection of Multiple Myeloma 1/Interferon Regulatory Factor 4 (MUM1/ IRF-4) in canine plasmacytoma: comparison with CD79a and CD20. Vet. Pathol. 44(6):875-884. <http://dx.doi.org/10.1354/vp.44-6-875> <PMid:18039900>

Rebhun R.B., Kent M.S., Borrofka S.A.E.B., Frazier S., Skorupski K. \& Rodriguez C.O. 2011. CHOP chemotherapy for the treatment of canine multicentric T-cell lymphoma. Vet. Comp. Oncol. 9(1):38-44.<http://dx.doi. org/10.1111/j.1476-5829.2010.00230.x><PMid:21303452>

Stefanello D., Valenti P., Zini E., Comazzi S., Gelain M.E., Roccabianca P., Avallone G., Caniatti M. \& Marconato L. 2011. Splenic marginal zone lymphoma in 5 dogs (2001-2008). J. Vet. Intern. Med. 25(1):90-93. <http://dx.doi. org/10.1111/j.1939-1676.2010.0639.x> <PMid:21092007>

Vail D.M., Pinkerton M.E. \& Young K.M. 2013. Withrow and MacEwen's Small Animal Clinical Oncology. 5th ed. W.B. Saunders, Missouri. 768p.

Valli V.E., Vernau W., de Lorimier L.-P., Graham P.S. \& Moore P.F. 2006. Canine indolent nodular lymphoma. Vet. Pathol. 43(3):241-256. <http://dx.doi. org/10.1354/vp.43-3-241> <PMid:16672571>

Valli V.E., Myint M.S., Barthel A., Bienzle D., Caswell J., Colbatzky F., Durham A., Ehrhart E.J., Johnson Y., Jones C., Kiupel M., Labelle P., Lester S., Miller M., Moore P., Moroff S., Roccabianca P., Ramos-Vara J., Ross A., Scase T., Tvedten H. \& Vernau W. 2011. Classification of canine malignant lymphomas according to the World Health Organization Criteria. Vet Pathol. 48(1):198211. <http://dx.doi.org/10.1177/0300985810379428><PMid:20861499>

Valli V.E., Kass P.H., San Myint M. \& Scott F. 2013. Canine lymphomas: association of classification type, disease stage, tumor subtype, mitotic rate, and treatment with survival. Vet. Pathol. 50(5):738-748. <http:// dx.doi.org/10.1177/0300985813478210><PMid:23444036>

Van Stee L.L., Boston S.E., Singh A., Romanelli G., Rubio-Guzman A. \& Scase T.J. 2015. Outcome and prognostic factors for canine splenic lymphoma treated by splenectomy (1995-2011). Vet Surg. 44(8):976-982. <http:// dx.doi.org/10.1111/vsu.12405><PMid:26426095>

Vezzali E., Parodi A.L., Marcato P.S. \& Bettini G. 2009. Histopathologic classification of 171 cases of canine and feline non-Hodgkin lymphoma according to the WHO. Vet. Comp. Oncol. 8(1):38-49. <http://dx.doi. org/10.1111/j.1476-5829.2009.00201.x><PMid:20230580> 